\title{
NILAI- NILAI PANCASILA DALAM MENANGANI INTOLERANSI DI INDONESIA
}

\author{
Sapta Baralaska Utama Siagian *
}

\author{
Dosen di Sekolah Tinggi Teologi Biblika Jakarta
}

Diterima: 3 Maret 2020; Disetujui: 23 Maret 2020; Dipublikasikan: 6 April 2020

\begin{abstract}
Abstrak
Ada dua fenomena yang muncul pasca jatuhnya rezim orde baru dan era reformasi tahun 1998 yaitu dihapuskannya kebijakan sosialisasi nilai nilai Pancasila dan UUD NRI 1945 dalam kehidupan sosial politik dan kemasyarakatan, aksi aksi radikalisme dan terorisme oleh kelompok kelompok radikal. Secara psikologis sosial masyarakat dalam posisi dilematis, sudah meninggalkan nilai keyakinan yang lama, tapi nilai tatanan baru belum tersedia. Euforia kebebasan dan reformasi telah mendorong munculnya paham paham baru yang belum tentu sesuai dengan nilai kehidupan berbangsa dan bernegara, salah satunya adalah munculnya kelompok kelompok keagamaan dengan faham radikal yang mendorong tindakan kekerasan ekstrimisme dan terorisme.Berdasarkan deskripsi kondisi ini, maka permasalahan utamanya yaitubelum optimalnya implementasi nilai nilai Pancasila dalam menghadapi radikalisme dan terorisme, sehingga mempengaruhi ketahanan ideologi yang pada akhirnya berdampak terhadap ketahanan nasional. Oleh karena itu diperlukan sebuah konsepsi yang tepat untuk mengatasinya.
\end{abstract}

Kata kunci: Nilai-nilai, Pancasila, Ketahanan, Ideologi

\section{Abstract}

There are two phenomena that emerged after the fall of the New Order regime and the 1998 reform era, namely the abolition of the socialization of the values of Pancasila and the 1945 Constitution of the Republic of Indonesia in socio-political and social life, acts of radicalism and terrorism by radical groups. Psychologically, the social community is in a dilemma, leaving the old belief values behind, but the new order values are not yet available. The euphoria of freedom and reformation has led to the emergence of new understandings that are not necessarily in accordance with the values of national and state life, one of which is the emergence of religious groups with radical views that encourage acts of violence, extremism and terrorism. The values of Pancasila in the face of radicalism and terrorism, thus affecting ideological resilience which in turn has an impact on national resilience. Therefore we need an appropriate conception to overcome it. Keywords: Values, Pancasila, Resilience, Ideology

How to Cite: Dr. Sapta Baralaska Utama Siagian, M.Th. (2020). Nilai- Nilai Pancasila Dalam Menangani Intoleransi di Indonesia. Jurnal Teologi Biblika, 5 (1): 36-45.

*Corresponding author: ISSN 2355-1704 (Print) 


\section{PENDAHULUAN}

Munculnya aksi radikalisme dan terorisme akibat kekosongan nilai ideologi Pancasila mulai muncul pada awal tahun 2000-an- setelah tragedi Bom WTC di Amerika Serikat tahun 2001-seperti tragedi Bom Bali tahun 2002 oleh Amrozy dkk, Aksi bom kedubes Australia, Bom Tanah Abang, Bom Bunuh diri Cirebon, Penembakan aparat polisi di Solo, aksi terorisme kelompok Noor Din M Top, Dr. Azahari, dan aksi teroris pimpinan kelompok Santoso, dan terakhir aksi terorisme di Sarinah Tamrin oleh Kelompok Bahrun Naim pada awal 2016. fenomena yang muncul pasca jatuhnya rezim orde baru dan munculnya era reformasi tahun 1998 yaitudihapuskannya kebijakan sosialisasi nilai nilai Pancasila dan UUD NRI 1945 dalam kehidupan sosial politik dan kemasyarakatan.

Kebijakan dan program Implementasi Nilai Nilai Pancasila dan UUD NRI 1945 Dalam Menghadapi Radikalisme dan Terorisme, guna meningkatkan Ketahanan Ideologi dalam rangka Ketahanan Nasional, merupakan sebuah program bersama yang melibatkan berbagai pihak yaitu negara, pemerintah dan masyarakat. Oleh sebab itu program ini memerlukan adanya sinergi dan kerjasama dari seluruh stakeholder terkait. Hal ini sangat penting karena persoalan radikalisme dan terorisme bukan semata menjadi ancaman dan tanggung jawab negara, tapi sudah menjadi ancaman kemanusiaan yang harus menjadi tanggung jawab kita semua untuk mengatasinya.

Oleh sebab itu,tulisan artikel ini menyajikan satu pemikiran yang berkaitan tentang Program Implementasi Nilai Nilai Pancasila dan UUD NRI 1945 yang harus sejalan dengan landasan filosofis, landasan konstitusional serta peraturan terkait lainnya, sehingga program ini bisa mendukung pencapaian tujuan pembangunan nasional. Program imlementasi Nilai Pancasila dan UUD NRI 1945dan harus memiliki landasan moral dan operasional yang sesuai dengan jiwa, semangat dan amanah konstitusi.

\section{METODE PENELITIAN}

Pendekatan penelitian ini merupakan penelitian kualitatif dengan menggunakan riset pustaka. Tehnik pengumpulan data yang digunakan oleh peneliti adalah: Pertama, dengan melakukan riset pustaka sesuai dengan pokok pembahsan. Kedua melakukan studi perbandingan.

\section{PEMBAHASAN}

\section{a. Pancasila Sebagai Landasan Idiologi}

Pancasila merupakan landasan idiil dalam mengatasi persoalan radikalisme dan terorisme. Gerakan radikalisme dan terorisme secara khusus bertentangan dengan tiga sila utama dalam pancasila yaitu Sila Ketuhanan Yang Maha Esa, sila Kemanusiaan yang Adil dan Beradab dan sila Persatuan Indonesia. Sila Ketuhanan berarti kita harus mempercayaidan mengimani keberadaan Allah SWT yang Mengajarkan sifat kasih sayang, menolak kekerasan dan toleransi. Gerakan radikalisme dan terorisme sangat bertentangan dengan sila Ketuhanan Yang Maha Esa karena bertentangan dengan sifat ketuhanan yang tidak boleh memaksakan kehendak dan menggunakan cara kekerasan dalam mencapai tujuan. Gerakan radikalisme dan terorisme juga bertentangan dengan Sila Kemanusiaan karena radikalisme dan terorisme mendorong munculnya tindakan kekerasan, pembunuhan, kematian yang bertentangan dengan nilai kemanusiaan dan tidak menghargai Hak Asasi Manusia (korankedaulatanrakyat, 2016). Gerakan radikalisme juga bertentangan dengan sila Persatuan Indonesia, karena adanya 
pemaksaan kehendak melalui cara cara kekerasan, dan keinginan untuk mengganti dasar negara Pancasila dengan dasar lainnya, akan merusak persatuan dan kesatuan bangsa (Devi ariani, 2015).

\section{b. UUD NRI 1945 sebagai Landasan Konstitusional}

Dalam pembukaan UUD NRI 1945, salah satu tugas negara adalah melindungi segenap tumpah darah Indonesia, memajukan kesejahteraan umum, mencerdaskan kehidupan bangsa dan ikut serta menciptakan perdamaian dunia. Keberadaan gerakan radikalisme dan terorisme merupakkan ancaman terhadap keamanan dan keselamatan seluruh warga bangsa. Negara wajib melindungi warganya dari segala bentuk ancaman kelompok kelompok radikal yang menggunakan cara cara kekerasan dan terorisme. Penanaman nilai nilai Pancasila dan UUD NRI 1945 dalam kehidupan berbangsa dan bernegara, diharapkan bisa memberikan imunitas atau kekebalan terhadap warga negara, untuk tidak terpengaruh dengan faham faham kelompok radikal yang menggunakan cara kekerasan dalam pencapaian tujuan. Implementasi nilai Pancasila dan UUD NRI 1945 bisa menjadi virus untuk mencegah muculnya radikalisme dan terorisme (deradikalisasi) secara lebih efektif dan efisien.

\section{c. Wawasan Nusantara sebagai Landasan Visional}

Pada awal kemerdekaan, berdirinya negara Indonesia tidak didasarkan karena kesamaan etnis, suku, agama, bahasa, budaya, dan kedaerahan. Akan tetapi berdirinya negara Indonesia karena - sebagaimana tercantum dalam pembukaan UUD NRI 1945-adanya keinginan untuk hidup bersama sebagai suatu bangsa dalam sebuah negara yang merdeka, bersatu, berdaulat, adil dan makmur. Hal itu juga diperkuat dalam Lambang negara Burung Garuda Pancasila dengan semboyannya Bhinneka Tunggal lka yang berarti berbeda beda tetapi tetap dalam satu kesatuan juga. Keragaman etnis, suku, agama, bahasa, dan budaya bukan alasan untuk kita berpecah belah sebagai sebuah bangsa. Perbedaan dan keragaman merupakan sebuah khazanah kekayaan bangsa yang bisa menjadi potensi atau kekuatan, bukan malah menjadi kendala dan penghambat terhadap persatuan dan kesatuan. Disinilah urgensinya kita sebagai sebuah bangsa mengelola sebuah keragaman dalam semangat persatuan (unity in diversity). Oleh sebab itu, adanya gerakan radikalisme dan terorisme yang cenderung menyeragamkan perbedaan, menjadi sebuah ancaman terhadap harmoni sosial dan persatuan nasional. Gerakan radikalisme keagamaan muncul karena adanya pemahaman yang sempit terhadap teks teks ajaran agama, dan juga masih adanya sekelompok kecil yang masih memiliki cita cita ideology yang berbeda bahkan berlawanan dengan cita cita nasional, yaitu keinginan mendirikan sebuah negara berdasarkan paham keagamaan satu kelompok tertentu, dan mengabaikan keragaman dan perbedaan dari kelompok lainnya.

\section{d. Ketahanan Nasional sebagai Landasan Operasional}

Hakikat ketahanan nasional Indonesia adalah keuletan dan ketangguhan bangsa yang mengandung kemampuan mengembangkan kekuatan nasional untuk dapat menjamin kelangsungan hidup bangsa dan negara dalam mencapai tujuan nasional. Hakikat konsepsi ketahanan nasional Indonesia adalah pengaturan dan penyelenggaraan kesejahteraan dan keamanan secara seimbang, serasi, dan selaras dalam seluruh aspek kehidupan nasional ( timPokja Geo,2016). Keberhasilan implementasi Nilai Pancasila dan UUD NRI 1945 dalam konteks kehidupan berbangsa dan bernegara, dalam menghadapi gerakan radikalisme dan terorisme, akan mampu memperkuat ketahanan nasional. Nilai nilai Pancasila dan UUD NRI 1945 
yang diyakini kebenarannya, dihayati dan diamalkan oleh warga negara Indonesia dalam perilaku kehidupan sosial sehari hari, bisa menjadi kekuatan efektif untuk menolak dan menangkal potensi munculnya benih benih radikalisme dan terorisme. Kekuatan ideologi Pancasila dan UUD NRI 1945 sebagai landasan idiil dan konstitusional, diharapkan bisa mencegah masuknya faham faham radikal dan aksi terorisme yang akan merusak persatuan dan kesatuan bangsa.

\section{Implementasi Nilai Pancasila}

Implementasi merupakan suatu proses penerapan ide,konsep, kebijakan, atau inovasi dalam suatu tindakan praktis sehinggamemberi dampak, baik berupa perubahan pengetahuan, keterampilanmaupun nilai, dan sikap. Dalam Oxford Advance Learner'sDictionary dikemukakan bahwa implementasi adalah "Put something intoeffect", (penerapan, sesuatu yang memberikan efek atau dampak). Sedangkan nilai nilai Pancasila adalah nilai nilai yang terdapat dalam lima sila Pancasila yaitu nilai ketuhanan, nilai kemanusiaan, nilai persatuan, nilai kerakyatan dan nilai keadilan sosial. Jadi implementasi nilai pancasila adalah sebuah proses penerapan, ide konsep, kebijakan untuk menerapkan atau mengaplikasikan lima nilai Pancasila dalam kehidupan individu, sosial kemasyarakatan dan kebangsaan.

\section{Radikalisme}

Munculnya perilaku radikalisme yang cenderung mengarah kepada kekerasan ekstrimisme (violent extrime) dari kelompok kelompok keagamaan, pada dasarnya merupakan sebuah tindakan menyimpang (deviasi) dari sebuah pemahaman teks menjadi sebuah tindakan sosial. Deviasi aktualisasi keberagamaan dari spirit damai kepada tindakan radikalisme yang cenderung menggunakan pendekatan-pendekatan kekerasan baik dalam konteks sosial dan politik dapat diindentifikasi dari dua aspek, (i) aspek internal, yaitu berupa emosi keagamaan yang berdasarkan interpretasi ajaran agama. dan (ii) aspek eksternal, yaitu lingkunganbudaya, sosial dan politik yang membentuk radikalisme keberagamaan, seperti pada masa represif politik Orde Baru (syamsulbakrie, 2004).

Dengan demikian, radikalisme dan kekerasan atas nama agama tidak disebabkan oleh variabel tunggal, yaitu internalisasi nilai keagamaan yang tekstualis (skripturalis), melainkan multi-variabel yang berinterseksi(Jonathan H.Turner,2005).Misalnya menyebut variabel emosi negatif yang terepresi. Variabel ini adalah hasil reduksi dari konsepsi (conception) teori interaksionisme simbolik dan lainnya. Ia mengamati secara kualitatif bentuk radikalisme yang berlandaskan kekerasan ekstrem dimana pelaku sanggup menjadi combattan bagi misi tertentu dengan impuls psikis.

Nilai keagamaan yang dikategorikan moderat berpotensi pula untuk menjalankan kekerasan agama yang ekstrem dalam bentuk serangan-serangan individual yang combattan. Hal ini merupakan modeling dari suatu penelitian kuantitatif (Andrew Kydd-Walter,2002) atas radikalisme yang berada dalam relasi negara dan organisasi para-militer dimana terjadi interaksi kepercayaan dan ketidakpercayaan antar negara dan organisasi para-militer dan internal organisasi para militer. Studi radikalisme (Kydd-Walter) menganalisis kekerasan ekstrem yang dilakukan individu Hamas (individu dari organisasi para-militer) terhadap Israel (negara). 


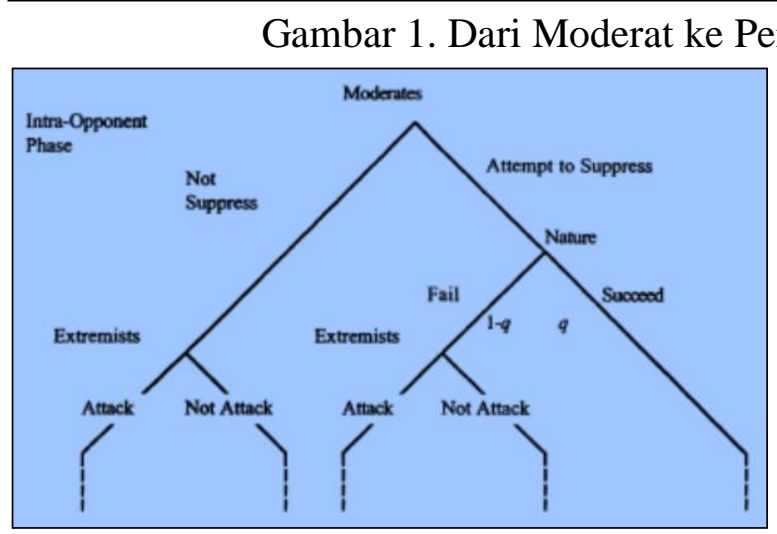

Salah satu bentuk radikalisme yang ekstrem dapat kita lihat dalam peristiwa bom bunuh diri yang terjadi beberapa kali di Indonesia. Perilaku tersebut tak-dapat lagi dinilai sebagai akumulasi dari tafsir skripturalis yang kedap kritik, sekaligus menandai jejaring baru dimana komunitas itu tumbuh dan eksis disamping politik aliran di Indonesia. "Ideological archaeology is not the answer," kata Amy Zalman. (Amy Zalman, 2008).

\section{Terorisme}

Terorisme adalah paham yang berpendapat bahwa penggunaancaracarakekerasan dan menimbulkan ketakutan adalah cara yang sah untuk mencapaitujuan(Muhammad aliSya'faat, 2003) Oleh sebab itu teror merupakan reaksi jahatyangdipandang "lebih jahat" oleh pelaku, sehingga bukan merupakan kejahatan yangberdirisendiri (interactionism) dan dapat dikelompokkan kedalam kejahatan balasdendam(hatecrimes) (Nazir Abas, 2012).

Awalnya terorisme dikategorikan sebagai kejahatan terhadap negara(CrimeAgainst State) tapi lambat laun berkembang menjadi kejahatan terhadapkemanusiaan(Crime Against Humanity). Terorisme memiliki berbagai karakteristik, salahsatukarakteristik terorisme adalah semangat radikalisme agama.Kelompokkelompokradikalis agamapun ditengarai menggunakan metode teror untukmencapaikepentingannya. Kekerasan politik dalam bentuk teror seringkali dijadikan alatuntukmencapai tujuan. Kelompok jihad Islam di Mesir, jihad Islam di Yaman NationalIsamicFront di Sudan, Al-Qaeda yang berbasis di Afganistan, Jamaah Islamiyah yangberbasis di Malaysia atau kelompok-kelompok radikal Yahudi seperti Haredi,Bush Emunim,KachKahenidiIsraeladalahsekedarcontohelemen-

elemendenganspiritradikalisme agama yang cenderung mengedepankan kekerasan danteror (Luqman Hakim, 2004).

Memasuki abad ke 21, modus operandi terorisme mulai berkembangdenganmengadopsikemajuanteknologikomunikasi,elektronik,transportasi danperkembangan ilmu pengetahuan di bidang kimiawi. Tragedi 11 September 2001 merupakan bukti konkrit dari perkembangan ini. Dua pesawat komersial AmerikaSerikat menabrak gedung kembar World Trade Center (WTC), dan salah satupesawatlagi menabrak Pentagon, gedung pusat pertahanan Amerika Serikat. Politik kambinghitam(Scape Goart Theory) pun dilancarkan untuk mengurangi rasa malu Negara yang mengaku sebagai adi kuasa.Penahanan dan pengadilan terhadap sejumlah individu dan kelompok di negara-negara Asia Tenggara seperti Malaysia, Singapura,Filipina,dan Indonesia atas tuduhan keterlibatan dalam aksi terorisme mengindikasikanbahwakelompok-kelompok tersebut memiliki keterkaitan secara regional satu sama lain,danjuga dengan kelompok-kelompok radikalinternasional (AzyumardiAzra, 2012).

Artikel ini merupakan bagian dari upaya deradikalisasi melalui pemahaman kembali nilai nilai Pancasila dan UUD NRI 1945, dalam menghadapi munculnya faham faham radikalisme dan terorisme di masyarakat. Pancasila dan UUD NRI 1945 
yang menjadi bagian dari 4 konsensus dasar yang bersumberkan dari nilai ajaran agama, kebudayaan, nilai-nilai yang berkembang di masyarakat diharapkan bisa menjadi budaya kearifan lokal dalam melakukan counter radikalisme melalui pelaksanaan nilai Pancasila.

Tentunya konsep implementasi Pancasila dan UUD NRI 1945 menggunakan pendekatan berbeda dibandingkan program sejenis yang pernah ada selama Orde Baru. Program implementasi Pancasila tidak hanya sekedar menyentuh aspek kognitif (pengetahuan) tapi juga sudah menyentuh level attitude dan psikomotorik, sehingga bisa menimbulkan kesadaran baru tentang urgensinya kembali kepada nilai nilai Pancasila. Model implementasi tidak lagi bersifat monolog, satu arah tapi sudah lebih dialogis dan demokratis. Implementasi nilai Pancasila tidak lagi bersifat elitis tapi sudah lebih populis karena sudah menjadi kesadaran bersama semua rakyat Indonesia. Sebuah kesadaran baru tentang pentingnya mengamalkan nilai Pancasila sebagai benteng terakhir menghadapi radikalisme dan terorisme atas nama keyakinan agama. Ada tiga faktor yang mempengaruhi munculnya radikalisme dan aksi terorisme diantaranya: (i) pemahaman teks suci keagamaan yang sempit, literalis dan tekstualis. Pemahaman sempit ini dilatar belakangi oleh bahan bacaan, lingkungan pergaulan, latar belakang pendidikan. Keberagamaan sempit ini membuat mereka mudah menganggap orang lain yang tidak sealiran sebagai kelompok yang sesat, kafir, sekuler dan labelling negative lainnya. (ii) rezim pemerintahan negara yang dianggap memusuhi kelompok agamanya. Negara dianggap musuh agama yang harus dilawan. Dasar negara yang tidak sesuai dengan keyakinannya harus dilawan dan tidak ditaati. Muncul upaya untuk melawan negara dan menggantikannya dengan rezim yang seagama dan se-ideology. Mereka akan melakukan tindakan radikal ekstrimis dan teroris dalam rangka memperjuangkan cita cita ideologinya. (iii) transformasi pemikiran, gagasan, ide dan gerakan dari luar negeri yang mencoba diadopsi dan direplikasi untuk diterapkan di Indonesia. Pemikiran politik keagamaan yang transnasionalisme ini tidak sesuai dengan cita cita bangsa Indonesia sebagaimana tercantum dalam Pancasila dan UUD NRI 1945

Penamanan nilai nilai Pancasila dan UUD NRI 1945 dengan model pendekatan yang lebih menarik, intelektual, akademis diharapkan bisa menjadi counter wacana terhadap pemahaman keberagamaan yang sempit. Pancasila tidak hanya sekedar teoritis belaka yang tidak bisa dilaksanakan, tapi ajaran Pancasila sudah hidup, menjadi perilaku dan akhlak para pendiri bangsa. Para founding father bangsa ini telah memperaktekkan nilai nilai Pancasila dan menjadi mata air keteladanan yang layak diteladani oleh generasi muda bangsa Indonesia (Yudi Latif, 2014). Karena dalam Pancasila kita belajar dan memahami pentingnya nilai nilai ketuhanan dengan sifat kasih sayangnya yang sangat menghormati HAM, kita belajar nilai kemanusiaan, keadilan dan keberadaban, nilai persatuan, nilai kerakyatan dan nilai keadilan sosial. Kelima nilai Pancasila tersebut selama ini terbukti mampu menjaga keutuhan bangsa sejak dulu hingga sekarang. Gagasan para pendiri bangsa tentang Pancasila seolah menjadi roh dasar dalam pembangunan kebangsaan yang sangat progresif dan revolusioner (Hariyono, 2014).

Kelima nilai Pancasila tersebut sangat kontra dengan nilai nilai kelompok radikalisme terorisme yang cenderung menghalalkan segala cara, menolak keberagaman, pro terhadap kekerasan dan tindakan kekejaman lainnya. Dengan kesadaran nilai nilai Pancasila dan UUD NRI 1945, maka tidak ada lagi radikalisme dan terorisme yang muncul atas nama agama, memaksakan kehendak untuk mengubah dasar negara dengan keyakinan ideology lain. Karena dengan Pancasila-lah, ideology yang bisa 
merancang dan menjadi arsitektur dalam membangun demokrasi bangsa ini sesuai dengan cita cita awal para pendiri bangsa (Haryono, 2013).

Konsep ketahanan nasional merupakan gabungan antara gatra ilmiah (trigatra) dan gatra dalam kehidupan sosial masyarakat dan politik (Pancagatra) yang meliputi ideology, politik, ekonomi, sosial budaya dan pertahanan keamanan (Ipoleksosbud dan Hankam). Aksi aksi radikalisme berdampak dan mengancam ketahanan nasional kita khususnya pada Panca Gatra yaitu:

\section{1) Ancaman terhadap IdeologiPancasila dan UUD 1945,}

Karena jelas aksi radikalisme dan terorisme merupakan sarana/tindakan antara karena tujuan akhir adalah merebut kekuasaan dan mengganti ideology negara Pancasila dan UUD NRI 1945 diganti dengan dasar negara yang bersumber dari idologi maupun ajaran keagamaan. Seperti yang dikatakan oleh Abu Bakar Baasyir, Amir Majelis Mujahidin Indonesia berpendapat bahwa Pancasila adalah rekayasa pihak Kristen/Katolik untuk menghancurkan institusi Islam di Indonesia (A.M.Hendropriyono,2009).Jadi radikalisme merupakan ancaman terhadap Pancasila dan UUD NRI 1945.

\section{2) Ancaman terhadap Keutuhan Politik,}

Aksi radikalisme bisa mengancam ketahanan nasional karena menimbulkan instabilitas politik, menurunkan kepercayaan negara negara luar terkait jaminan keamanan investasi dan rasa aman didalam negeri. Kasus Bom Bali, Bom Kedubes Australia, Bom Polres Cirebon memperlihatkan bahwa sasaran terorisme sudah sangat beragam tidak lagi rakyat sipil, tapi sudah kepada aparatur negara, kedutaan asing dan warga asing di Indonesia.

\section{3) Stabilitas Perekonomian terganggu,}

Aksi radikalisme dan terorisme bisa mengganggu perekonomian karena mempengaruhi nilai tukar rupiah, harga rupiah menjadi anjlok dan dolar naik. Akibatnya harga kebutuhan menjadi semakin mahal, daya beli rakyat melemah, investor ketakutan bahkan mereka menarik modalnya dari Indonesia, PHK dimana mana, sehingga timbul kekacauan dimana mana.

\section{4) Sosial Budaya,}

Aksi radikalisme dan terorisme bisa merusak tatanan budaya masyarakat dan mengganggu kohesifitas sosial. Masyarakat menjadi mudah curiga terhadap orang lain, tidak ada lagi rasa toleransi dan perdamaian, karena mereka menjadi mudah terhasut dan terprovokasi. Dari aspek budaya, aksi radikalisme dan terorisme bisa merusak tatanan budaya masyarkat Indonesia yang selama ini dikenal sangat toleran, beradab, sopan santun, lemah lembut menjadi budaya yang beringas, kasar, barbar dan biadab.

\section{5) Pertahanan dan Keamanan,}

Aksi radikalisme dan terorisme telah mengakibatkan korban luka dan kematian bagi mereka yang tidak bersalah. Dari aspek pertahanan, aksi radikalisme terorisme membuat kekuatan pertahanan lebih banyak dikonsentrasikan untuk menghadapi kelompok radikalis teroris, ketimbang menghadapi serangan dari luar. Dari sisi keamanan, aksi radikalisme telah menciptakan gangguan instabilitas keamanan karena akan menimbulkan rasa cemas, ketakutan orang untuk berada di 
Jurnal Teologi Biblika, Vol. 5, No. 1, Edisi April 2020

Sapta Baralaska Siagian, Nilai-nilai Pancasila dalam menangani Intoleransi di Indonesia,

Hal: $36-45$

kawasan umum karena khawatir ada serangan bom bunuh diri dan lainnya. Orang mulai mencurigai dan menjadi paranoid terhadap setiap orang asing di wilayahnya.

\section{Kontribusi Nilai Pancasila terhadap Ketahanan Nasional}

Dengan penanaman nilai Pancasila yang terus menerus, intensif, massif, terkoordinasi dan terintegrasi dengan baik, akan membuat faham dan gerakan radikal menjadi mati dan tidak berkembang.Gerakan radikal mati karena sudah tidak ada lagi orang yang mau terlibat dan berjuang bersamanya. Mereka tidak mau dibodohi dengan ideologi maut yang membuat mereka mati sia sia.

Dengan matinya gerakan dan ideologi radikal, maka akan berdampak terhadap suasana kehidupan sosial masyarakat yang lebih tenang, damai, aman dan tanpa ada rasa ketakutan. Suasana ini akan berdampak terhadap ketahanan ideologi Pancasila karena ajaran Pancasila semakin bisa dipercaya dan dirasakan kebenarannya. Ketahanan ideologi Pancasila pada akhirnya akan berdampak terhadap ketahanan nasional bangsa Indonesia.

Oleh sebab itu perlu sebuah kebijakan yang komprehensif dan terpadu dalam penanaman Nilai-Nilai Pancasila dan UUD NRI 1945 sehingga hasilnya bisa lebih optimal. Kebijakan tersebut harus didukung oleh dengan langkah-langkah strategis dan upaya upaya teknis untuk melaksanakan strategi tersebut pada tingkat operasional. Dengan Kebijakan, Strategi dan Upaya yang lebih kongkrit, pemerintah dan jajarannya bersama masyarakat dapat bersinergi melakukan penanaman NilaiNilai Pancasila dan UUD NRI 1945 sebagai bagian deradikalisasi dalam menghadapi radikalisme dan terorisme.

\section{SIMPULAN}

Munculnya aksi aksi radikalisme dan terorisme telah menjadi ancaman nyata bagi kelangsungan ideologi Pancasila dan keutuhan NKRI. Ideologi radikal yang menggunakan cara-cara kekerasan, teror, menebar ancaman, kebencian telah menimbulkan instabilitas politik dan keamanan, mengganggu perekonomian Indoensia karena membuat investor luar takut untuk datang dan berinvestasi, jatuhnya nilai tukar rupiah,tidak adanya jaminan kepastian hukum dan keamanan serta mengancam persatuan dan kesatuan. Ideologi radikalisme juga bertentangan dengan Nilai-Nilai Pancasila yaitu nilai ketuhanan, nilai kemanusiaan, nilai persatuan, nilai kerakyatan dan nilai keadilan sosial.

Ancaman terhadap ideologi Pancasila dan UUD NRI 1945 secara langsung berdampak terhadap ketahanan nasional. Dengan tidak adanya Pancasila sebagai dasar negara, maka tidak ada lagi ideologi yang bisa menyatukan keragaman (Suku, etnis, agama, budaya, bahasa) sehingga mengancam persatuan dan kesatuan bangsa. Pancasila tidak lagi berfungsi sebagai simbol pemersatu bangsa karena sudah digantikan dengan ideologi lain. Kondisi ini akan berdampak terhadap ketahanan nasional karena bisa mengganggu dan menghancurkan eksistensi sebuah bangsa yang bernama Indonesia.

Kebijakan program penanaman nilai Pancasila dan UUD NRI 1945 saat ini dipandang penting dan memiliki relevansi mengingat kondisi bangsa yang masih menghadapi ancaman dari kelompok kelompok radikal teroris. Penanaman nilai Pancasila tentunya berbeda dengan apa yang pernah dilakukan di era Orde Baru. Penanaman nilai Pancasila yang sekarang ini dilakukan pada era demokrasi yang penuh kebebasan dan keterbukaan. Tujuannya bukan untuk mempertahankan rezim negara, tapi untuk menjaga keutuhan bangsa, menciptakan kondisi negara yang damai, aman, tenteram, toleran, menghargari perbedaan dan keragaman 
Kebijakan penanaman nilai Pancasila harus dilakukan secara sinergi dan koordinatif dengan melibatkan berbagai sektor yang ada, dan konten materinya harus komprehensif, integral dan berkelanjutan dengan memperhatikan kondisi sasaran peserta, latar pendidikan, pengalaman, usia dengan metode pendekatan yang dialogis, demokratis dan partisipatif.

\section{DAFTAR PUSTAKA}

A.M. Hendropriyono, Terorisme: 2009. Fundamentalisme Kristen, Yahudi, dan Islam, Jakarta: Kompas.

Adaptasi dari Andrew Kydd; Barbara F. Walter, "Sabotaging the Peace: The Politics of Extremist Violence", International Organization, Vol. 56, No. 2. (Spring, 2002), hal. 267.

Amy Zalman, "Countering Violent Extremism: Beyond Words," Policy Paper 5/2008, The EastWest Institute.

Azyumardi Azra, Islam Politik Radikal di Indonesia : Akar Ideologi Terorisme, Makalah disampaikan pada Diskusi Kajian tentang Terorisme di DitjenstrahanKemhan tanggal 16 Januari2012.

Departemen Pendidikan Nasional, 2005. Kamus Besar Bahasa Indonesia, (edisi ketiga). Jakarta: Balai Pustaka.

Devi Ariyani, 2015. fenomena Gerakan Radikalisme ISIS di Indonesia: Analisis Isi terhadap pemberitaan media online Mengenai Gerakan ISIS di Indonesia, FKIP Universitas Muhammadiyah Surakarta.

Eko Prasetyo, 2002, Membela Agama Tuhan: Potret Gerakan Islam dalam Pusaran Konflik Global, Yogyakarta: Resist Book.

Hariyono, 2014. Ideologi Pancasila; Roh Progresif Nasonalisme Indonesia, Malang: Instrans Publishing.

Haryono, 2013. Arsitektur Demokrasi Indonesi, Malang: Setara Press.

Jonathan H. Turner, "Self, Emotions, and Extreme Violence: Extending Symbolic Interactionist Theorizing," Symbolic Interaction, Vol. 30, Issue 4.

Koran Kedaulatan Rakyat, Terorisme Tetap Menjadi Ancaman, edisi 15/11/2015 links;http://www.krjogja.com/web/news/read/281208/terorisme_tetap_jadi_an caman di download 22 April 2016.

Luqman Hakim, 2004. Terorisme Indonesia, Forum Studi Islam, Surakarta : Surakarta FSIS.

Muchamad Ali Syafa'at, 2003. Tindak Pidana Teror Belenggu Baru bagi Kebebasan dalam "terrorism, definisi, aksidan regulasi," Jakarta: Imparsial.

Nasir Abas, Kajian tentang Terorisme, Makalah disampaikan pada Diskusi Kajian tentang Terorisme di Ditjenstarahan Kemhan tanggal 16 Januari 2012.

Noorhaidi Hasan, 2008. Laskar Jihad; Islam, Militansi, dan Pencarian Identitas di Indonesia Pasca Orde Baru, Jakarta; LP3ES.

Petrus Reinhard Golose, 2009. Deradikalisasi Terorisme: Humanis, Soul Approach dan Menyentuh Akar Rumput, Jakarta: Penerbit YPKIK.

Rizal Sukma,2003, Indonesia and the Challenge of Radical Islam After October 12, dalam Kumar Ramakrishna dan See Seng Tan (ed.), After Bali: The Threat of Terrorism in Southeast Asia, Singapore, Institute of Defence and Strategic Studies Nanyang Technological University.

Syamsul Bakrie, Islam dan Wacana Radikalisme Agama Kontemporer, DINIKA Vol. 3 No. 1, Januari 2004.

Tim Pokja Geo Strategi dan Konsep Ketahanan Nasional, 2016. Geo Strategi dan Konsep Ketahanan Nasional, Lemhanas RI. 
Yudi Latif, 2014. Mata Air Keteladanan: Pancasila Dalam Perbuatan, Bandung. Mizan.

Zachary Abuza, 2003. The War on Terrorism in Southeast Asia, dalam Richard J. Ellings (et.al.) (ed.), Strategic Asia 2003-4: Fragility and Crisis, (Seattle, National Bureau of Asian Research ) 